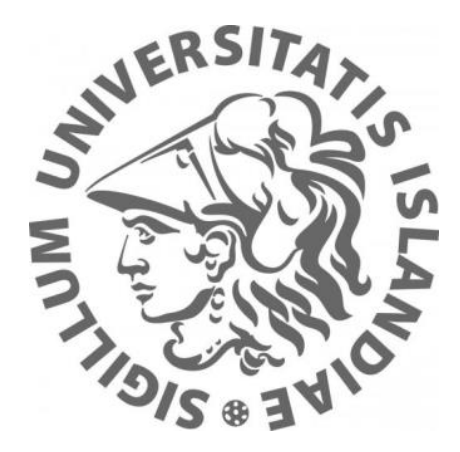

\title{
Otolith-based discrimination of cod ecotypes and the effect of growth rate
}

\author{
Einar Pétur Jónsson
}

Faculty of Life and Environmental Sciences

University of Iceland

2020 



\title{
Otolith-based discrimination of cod ecotypes and the effect of growth rate
}

\author{
Einar Pétur Jónsson \\ 90 ECTS thesis submitted in partial fulfillment of a \\ Magister Scientiarum degree in Biology \\ MS Committee \\ Steven E. Campana \\ Arnar Pálsson \\ Jón Sólmundsson \\ Master's Examiner \\ Klara Jakobsdóttir
}

Faculty of Life and Environmental Sciences

School of Engineering and Natural Sciences

University of Iceland

Reykjavik, September 2020 
Otolith-based discrimination of cod ecotypes and the effect of growth rate Cod ecotypes, otolith shape and growth rate 90 ECTS thesis submitted in partial fulfillment of a Magister Scientiarum degree in Biology

Copyright @ 2020 Einar Pétur Jónsson

All rights reserved

Faculty of Life and Environmental Sciences

School of Engineering and Natural Sciences

University of Iceland

Askja, Sturlugata 7

102, Reykjavik

Iceland

Telephone: 5254000

Bibliographic information:

Einar Pétur Jónsson, 2020, Otolith-based discrimination of cod ecotypes and the effect of growth rate, Master's thesis, Faculty of Life and Environmental Sciences, University of Iceland.

Printing: Háskólaprent, Fálkagata 2, 107 Reykjavík

Reykjavik, Iceland, September 2020 


\section{Abstract}

Otolith shape has previously been used to identify ecotypes within the Icelandic cod (Gadus morhua) stock and growth rate has repeatedly been found to be a strong contributing factor to otolith shape variation in fish. To examine the effect of growth rate on the relationship between otolith shape and cod ecotypes (using Pan I genotypes as proxies for ecotypes), 826 archived sagittal otoliths from a 52 year sampling period were retrieved, the individual growth rate calculated and otolith shape described, using both Normalized Elliptic Fourier transform and Discrete Wavelet transform. Discriminant functions of otolith shape yielded low ecotype classification success, both when using Fourier and Wavelet descriptors. High classification success was significantly lowered by the shape variability of an intermediate ecotype, while otolith shape was significantly affected by growth rate and cohort. Growth rate differences commonly reported for the ecotypes were present, but were less marked than expected and indeed, growth rate variance attributable to ecotype identity was dwarfed by cohort- and location-related variance in growth. This suggests that cod ecotype discrimination based on otolith shape is sensitive to both temporal and spatial variations in growth, as these can mask the effect of ecotype-related growth rate differences on otolith shape.

\section{Útdráttur}

Kvarnalögun hefur áður verið notuð til greiningar vistgerða innan íslenska porskstofnsins og sterkra áhrifa vaxtarhraða á kvarnalögun ítrekað gætt í ýmsum tegundum fiska. Með pað markmið að rannsaka áhrif vaxtarhraða á tengsl kvarnalögunar og vistgerða porsks (skilgreindar með breytileika á Pan I genastæðinu), var sótt í safn 826 kvarna frá 52 ára tímabili, vaxtarhraði hverrar kvarnar reiknaður og kvarnalögun lýst, og til pess notuð bæði Normalized Elliptic Fourier transform og Discrete Wavelet transform. Lítill árangur fékkst af flokkun vistgerðanna með aðgreiningarföllum á kvarnalögun, hvort heldur með Fourier eða Wavelet stuðlum. Fjölbreytt kvarnalögun mið-vistgerðar olli lágri flokkun, og bæði vaxtarhraði og árgangur höfðu marktæk áhrif á kvarnalögun. Vaxtarhraðamynstur vistgerðanna var ekki eins skýrt og í fyrri rannsóknum, en í raun féll breytileiki í vaxtarhraða vegna vistgerða í skugga breytileika af völdum árganga og svæða. Petta bendir til pess að aðgreining vistgerða porsks út frá kvarnalögun sé viðkvæm fyrir breytileika á vaxtarhraða í bæði tíma og rúmi, par sem sá breytileiki getur hulið mun á vaxtarhraða milli vistgerða, og par með mun á kvarnalögun milli vistgerða. 


\section{Table of Contents}

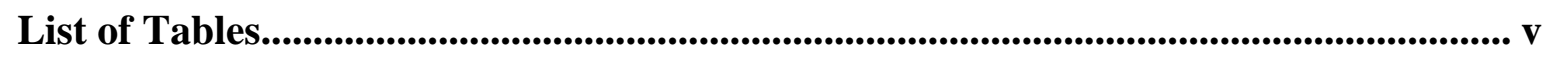

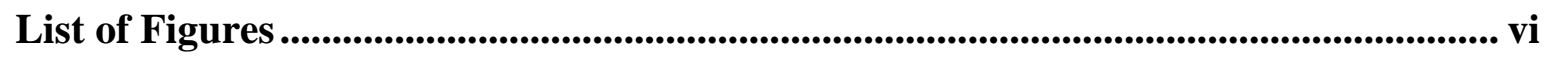

Acknowledgements........................................................................................................................ vii

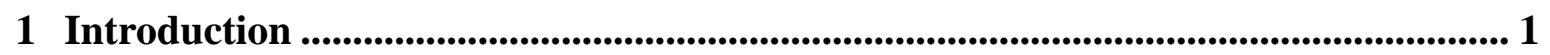

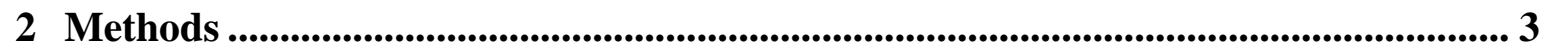

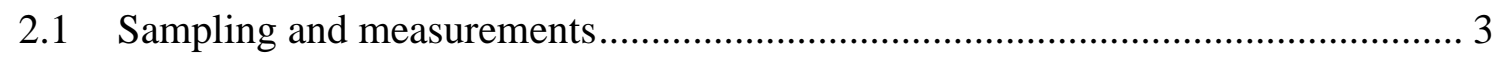

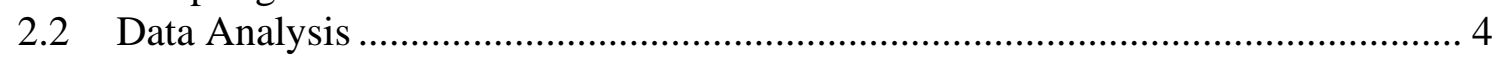

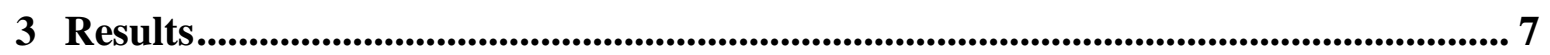

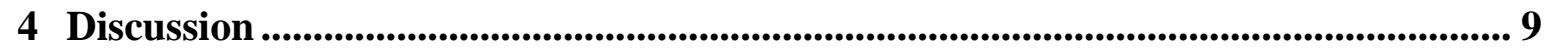

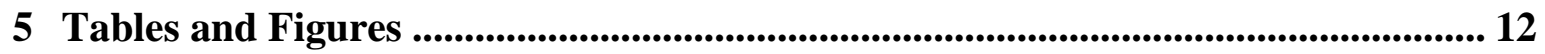

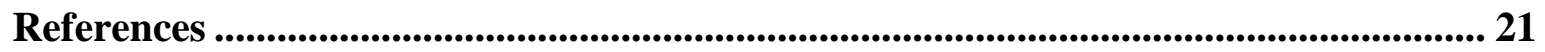




\section{List of Tables}

Table 1. Overview of the Pan I genetically identified samples originally presented in

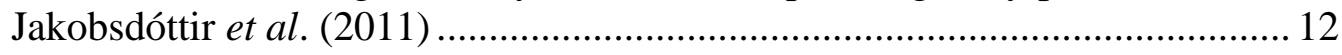

Table 2. Classification success of the Pan I genotypes by Discriminant Function Analyses of otolith shape

Table 3. Classification success (\%) of the Pan $\mathrm{I}^{\mathrm{AA}}$ and $\operatorname{Pan} \mathrm{I}^{\mathrm{BB}}$ genotypes by Discriminant function analyses of otolith shape....

Table 4. Results of a three-way ANOVA evaluating the relative effect of location, cohort and Pan I identity on the growth rate index $(G)$, as well as their twoway interactions 


\section{List of Figures}

Figure 1. Map of the sampling locations ................................................................. 15

Figure 2. A von Bertalanffy growth curve fitted to the length-at-age data......................... 16

Figure 3. Relative proportions of the three Pan I genotypes across cohorts in the three

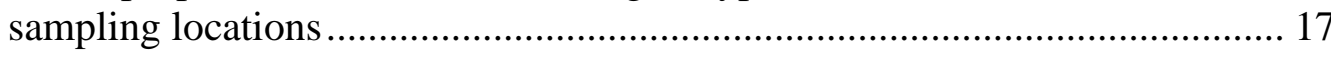

Figure 4. Distribution of the three Pan I genotypes along the discriminant scores from a Discriminant function analysis of the Pan $\mathrm{I}^{\mathrm{AA}}$ and Pan $\mathrm{I}^{\mathrm{BB}}$ genotypes using Wavelet coefficients, cohort and the growth rate index $(G) \ldots \ldots \ldots \ldots \ldots . . . . . .18$

Figure 5. Growth rate index $(G)$ of the ecotypes represented by the Pan I genotype ......... 19

Figure 6. Variation in the growth rate index $(G)$ across cohorts and among locations....... 19

Figure 7. Growth rate $(G)$ of the Pan I genotypes across cohorts in the Southwest

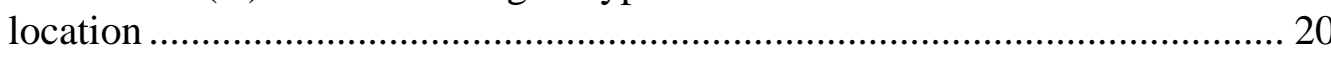




\section{Acknowledgements}

This work builds upon previous research conducted by Klara Jakobsdóttir (2011) and Hlynur Bárðarson (2016), on whose shoulders I now gratefully stand.

Staff of the Marine and Freshwater Research Institute (MFRI) collected and archived the samples used in the study, as well as supporting the current research with equipment, facilities and a helping hand.

Statistical support was given by Denis Warshan, Bjarki Elvarsson and Sölvi Rögnvaldsson.

Many thanks to Jón Sólmundsson of the MFRI for his guidance and introduction to the current field of research.

Special thanks to Professor Steven E. Campana, his supervision and valuable mentorship have formed and motivated a young scientist. 



\section{Introduction}

Ecotypes are sub-groups of populations differing in allele frequency across loci, formed through their multiple trait adaptations to environmental variables (Lowry, 2012). The ecological separation that is entailed in the formation of ecotypes has been linked to niche partitioning, where a single species may occupy a wider environmental gradient through a number of distinct ecotypes within the species, as exemplified by the cyanobacterium Prochlorococcus (Johnson et al., 2006) and lake whitefish (Coregonus clupeaformis) (Rogers et al., 2002). The ecotype stage has been suggested to be precursive to evolutionary processes such as speciation and this divergence has been studied extensively (see Lowry, 2012) since Turesson's (1922) studies on saltbushes in Sweden, where he coined the ecotype term. Studies on ecotypes and the divergence they entail are now common in fish, such as in Arctic char (Salvelinus alpinus) (Kapralova et al., 2013) and Atlantic cod (Grabowski et al., 2011). Increased importance is now given to maintaining the diversity that ecotypes confer to species and ecosystems, especially in the context of sustainable fisheries management (Wood et al., 2008; Knutsen et al., 2018).

Two distinct ecotypes of Atlantic cod (Gadus morhua) have been repeatedly reported from throughout the trans-oceanic range of the species (Pálsson and Thorsteinsson, 2003; Robichaud and Rose, 2004; Pampoulie et al., 2008). Off the coast of Iceland, Data Storage Tag (DST) profiles have identified a coastal ecotype and a more migratory (frontal) ecotype associated with thermal fronts (Thorsteinsson et al., 2012; Grabowski et al., 2011). In addition, there is evidence of fine-scale differences in spawning habitat selection between the ecotypes (Grabowski et al., 2011). The ecotypes present morphological differences (Jónsdóttir et al., 2008; Pardoe and Marteinsdóttir, 2009), as well as genetic divergence at the pantophysin I locus (Pan I). The Pan $\mathrm{I}^{\mathrm{AA}}$ genotype is associated with the coastal ecotype and the Pan $\mathrm{I}^{\mathrm{BB}}$ genotype with the frontal ecotype (Pampoulie et al. 2006, 2008; Árnason et al. 2009), while the Pan $\mathrm{I}^{\mathrm{AB}}$ presents intermediate behaviour (Bardarson et al., 2016).

Discrimination of stock components is important in fisheries science, where otoliths have proven to be a convenient tool (Campana and Casselman, 1993; Begg and Brown, 2011). Otoliths are metabolically inert structures with many varied uses, such as age reading and the discriminations of stocks (Campana, 2005). The otolith's shape is unique to each species and both internal and external otolith shape have been used to discriminate between stock components (Campana and Casselman, 1993; Cardinale et al., 2004; Stransky et al., 2008). The external otolith shape has recently been used to predict the ecotype identity of cod around Iceland, with DST profiles and Pan I genotyping used to validate the results (Bardarson et al., 2016).

Otolith shape variation has been associated with both intrinsic and extrinsic factors, but some of these have been suggested to be ultimately acting on otolith shape through growth variability among individuals. Genetic regulation of otolith shape has been detected, but these studies have also identified environmental determinants of otolith shape, suggesting dual shape regulation (Vignon and Morat, 2010; Cardinale et al., 2004). Despite the influence of environmental factors such as diet (Hüssy, 2008) and temperature (Lombarte and Lleonart, 1993) on otolith shape, a stronger link has been discovered between otolith 
shape and fish growth rate (Campana and Casselman, 1993). Environmental factors affecting otolith shape have also been proposed to be acting via individual growth rate (Cardinale $e t$ al., 2004; Denechaud, 2020). The coastal cod ecotype around Iceland has been found to grow faster than its frontal counterpart (Jónsdóttir et al., 2002; Pálsson and Thorsteinsson, 2003; Jakobsdóttir et al., 2011), although this finding is not universal (Jónsdottir et al., 2008). Although growth rate's effect on otolith shape differences between cod ecotypes has not been confirmed, it is reasonable to assume the relationship exists as it does in the case of separate cod stocks, where otolith shape differences were driven by growth rate (Campana \& Casselmann, 1993).

The objective of this study was to investigate the effect of growth rate on the relationship between otolith shape and the cod ecotypes off Iceland. The study examined cod from three separate spawning grounds collected over a period of half a century. Archived otoliths were retrieved and their shape described using Normalized Elliptic Fourier transform and Discrete Wavelet transform. These had already been genotyped for the Pan I locus (by Jakobsdóttir et al., 2011), which was used as a proxy for ecotype identity. Ecotype discrimination using otolith shape was tested and the relative contributions of cohort, location and growth rate to the shape variation were evaluated. We hypothesized that ecotype discrimination based on otolith shape would be sensitive to spatial and temporal variations in fish growth rate. 


\section{Methods}

\subsection{Sampling and measurements}

Samples of Icelandic cod were collected both at port and on surveys by the Icelandic Marine Research Institute (MRI) using three types of commercial fishing gear between 1948 and 2000 (Table 1). Cod were caught from late March through April (season of spawning) at three known spawning grounds (Marteinsdottir et al., 2000) west and southwest of Iceland: Breiðafjörður (BRE), Faxaflói (FAX) and the southwest (SW) (Figure 1).

The total length of each cod was measured and their stage of sexual maturity determined. Sagittal otoliths were removed from the fish and their age estimated by experienced otolith age-readers. The otolith growth increments were counted from the core to the edge of the otolith in a transverse section through the otolith core, perpendicular to the otolith's longest axis. The age range was from 6 to 14 years.

Otolith shape analysis was based on the intact (unaged) sagittal otolith of each pair, which was photographed and measured following the methods detailed in Bardarson et al. (2016). The right sagittal otolith, with the sulcus acusticus facing up and the dorsal side pointing towards the top of the image, was photographed under a Leica MZ6 stereomicroscope at $0.63 x$ magnification using a Plan Apo $0.4 x$ objective. In cases where the right otolith had been sectioned for ageing, the left otolith was flipped horizontally and used instead. Strong backlighting of the otolith resulted in a contrasting dark shape on a light background. The images were then converted to 8-bit binary images, creating a black shape on a white background, followed by measurement of the otolith's maximum Feret diameter (the maximum distance between any two points on the otolith's edge). All image manipulation and measurements were carried out with the Fiji software (Schindelin et al., 2012). In order to maintain sample size, broken otoliths were glued together when possible, following Bardarson et al., (2014).

The shape of the otolith perimeter was analysed using the ShapeR package (Libungan and Pálsson, 2015) for the R software (R Core Team, 2020). In this procedure, the dark otolith was distinguished from the white background and the otolith's outline detected. Two independent methods were used to generate shape coefficients from the otolith outline: (1) Normalized Elliptic Fourier transform generated 45 Normalized Fourier coefficients that describe and quantify the shape with sines and cosines (Libungan and Pálsson, 2015). The Fourier coefficients were normalized with regards to otolith length (maximum Feret diameter), as part of the Normalized Elliptic Fourier analysis. (2) Discrete Wavelet transform was better suited for the description of localized changes in shape, such as sharp edges, as the 64 Wavelet coefficients detect shape variations at specific regions of the otolith (Graps, 1995; Libungan and Pálsson, 2015).

All shape coefficients were used in the analyses. The accuracy of shape description generally improves as the number of shape coefficients are increased, although the first 10 Fourier coefficients commonly describe most of the shape (Campana and Casselman, 1993; Bardarson et al., 2016). 
The otolith shape coefficients were detrended to remove any correlation with fish length. For each shape coefficient significantly affected by fish length, a general linear model (GLM) was fitted with the shape coefficient as a function of fish length and location. The shape coefficient was then detrended by subtracting from it the product of the fish length and the within-group slope $(\beta)$ acquired from the GLM. The resulting detrended shape coefficient was thus comparable among fish of different lengths from different locations.

The Pan I locus genotype was used as the exclusive indicator for ecotype identity, as the AA genotype is associated with the coastal ecotype, the BB genotype with the frontal ecotype, while the heterozygote $\mathrm{AB}$ is intermediate between frontal and coastal (Bardarson et al., 2016). This genetic information was obtained from tissue remaining on the otoliths as reported by Jakobsdóttir et al. (2011).

\subsection{Data analysis}

To analyse all age groups simultaneously and still retain a relative measure of fish growth rate, a growth rate index was created. This was done by first fitting a von Bertalanffy growth equation to length-at-age data using nonlinear least squares (Figure 2).

$$
E[L \mid t]=L_{1}+\left(L_{3}-L_{1}\right) * \frac{1-r^{2 * \frac{t-t_{1}}{t_{3}-t_{1}}}}{1-r^{2}}
$$

where

$$
r=\frac{L_{3}-L_{2}}{L_{2}-L_{1}}
$$

Equation 1. The von Bertalanffy growth function as re-parametrized by Francis (1988). $L_{1}, L_{2}$ and $L_{3}$ represent length at ages $t_{1}, t_{2}$ and $t_{3}$, respectively.

The von Bertalanffy function was fitted to the data using the function $v b f r$ from the fishmethods package (Nelson, 2018) for R. A growth rate index $(G)$ was defined as the 
residual $\left(r e s_{i}\right)$ for a given individual fish $i$ at age $j$ from the length predicted by the von Bertalanffy growth function at that age $\left(\hat{\mathrm{y}}_{j}\right)$. Calculation of $G$ allowed comparison of relative growth rates across age groups. An age-independent growth rate index has seldom been reported, so its validity was confirmed through comparison with length-at-age presentation of the data.

Discriminant function analysis (DFA) was used to identify the shape coefficients most effective in discriminating among the Pan I groups. Classification accuracy was assessed using cross validation where the prior probabilities were computed from the group sizes.

Analyses of Variance (ANOVAs) were used to evaluate the variance of growth rate among ecotypes, locations and cohorts. A Shapiro-Wilks test indicated non-normality of the distribution of residuals for the ANOVAs, but as the analyses are robust to modest deviations such as these, they were carried out nonetheless.

SPSS version 26 (IBM Corp., 2019) and the R software (version 3.6.1) were used for all statistical analyses in the study. 



\section{Results}

Of the three Pan I genotypes, AB was generally the most numerous, accounting for a mean proportion of 0.60 across cohorts and locations, while the mean proportion of AA was 0.24 and that of BB 0.16. There were clear changes in Pan I proportions through time, although not among locations (Figure 3). There were significant differences in Pan I proportions across cohorts (Chi-squared test, $p<0.01, \mathrm{n}=826$ ). The most prominent cohort-related variations were the inversions in the proportions of the AA and $\mathrm{AB}$ genotypes. However, these cohort-specific Pan I proportions did not vary significantly between the three locations (Chi-squared test, $p>0.05, \mathrm{n}=826$ ).

Otolith shape analysis allowed the Pan I genotypes to be identified, but with relatively low accuracy. Stepwise Discriminant function analyses (DFAs) of Pan I genotypes using either Fourier descriptors or Wavelet coefficients resulted in two significant discriminant functions incorporating up to 10 Fourier coefficients in one analysis and 15 Wavelet coefficients in the other. Cohort and $G$ were selected in both DFAs, while location was not selected at any step in either analysis $(p<0.01, \mathrm{n}=826)$. Classification success using these discriminant functions was $68 \%$, which was similar to DFA functions without cohort and $G$. The classification success was in all cases highest for $\mathrm{AB}$ (92-95\%), the most numerous of the Pan I genotypes, while AA and BB were classified with $17-40 \%$ and $2-5 \%$ success, respectively (Table 2), and both were most commonly (60-90\%) misclassified as AB.

Discriminant function analyses including only the $\operatorname{Pan} \mathrm{I}^{\mathrm{AA}}$ and $\operatorname{Pan} \mathrm{I}^{\mathrm{BB}}$ genotypes showed markedly higher classification success for these genotypes than the DFAs including all three genotypes. Stepwise DFAs incorporated 10 Fourier and 9 Wavelet descriptors (as well as cohort and the growth rate index $(G)$ ) and classified the $\operatorname{Pan} \mathrm{I}^{\mathrm{AA}}$ and $\operatorname{Pan} \mathrm{I}^{\mathrm{BB}}$ genotypes with over 85 and $72 \%$ success, respectively (Table 3). The Pan $\mathrm{I}^{\mathrm{AA}}$ and Pan $\mathrm{I}^{\mathrm{BB}}$ genotypes separated along the discriminant scores from the functions of the two DFAs, while the AB genotype was distributed over the whole range of these (Figure 4).

Although the Pan I genotype could be predicted in part by otolith shape, otolith shape in turn was significantly influenced by the growth rate of the fish. Multivariate General linear models indicated that $G$ significantly affected 18 of the 42 Fourier descriptors and 16 of the 63 Wavelets. Adding location, cohort and the Pan I identity to the analysis revealed that neither location nor Pan I identity had a significant effect on shape, while both $G$ and cohort had a significant effect on these shape descriptors, with cohort and its interaction with $G$ contributing most to the model ( $p<0.01, \mathrm{n}=826$ for all analyses).

The growth rate of the three genotypes differed at the gross scale, but these differences disappeared once account was taken of growth rate differences across location and cohort. A one-way Analysis of Variance (ANOVA) revealed statistically significant differences in $G$ among the Pan I genotypes when all data were pooled $(F(2,826), p<0.01$, Figure 5). A post-hoc Tukey's test indicated that $G$ for the $P a n \mathrm{I}^{\mathrm{AA}}$ genotype differed significantly from the $\mathrm{AB}$ and $\mathrm{BB}$ genotypes $(p<0.05)$ and that the latter two did not differ between themselves. However, when accounting for location and cohort, there were significant variations in $G$ among locations $(F(2,826), p<0.001)$ and cohorts $(F(55,826), p<0.001$, Figure 6$)$, but not 
among the Pan I genotypes $(F(2,826), p=0.638)$ (3-way ANOVA, see Table 4). The only significant interaction in the analysis was that between location and cohort $(F(19,826)$, $p<0.01)$.

Differences in fish growth rate between genotypes were not consistent when accounting for location. One-way ANOVAs revealed significant differences in $G$ between the Pan I genotypes in both Faxaflói $(F(2,207), p<0.01)$ and the Southwest $(F(2,473), p<0.01)$, and post-hoc Tukey's tests showed this to be the AA genotype separating from the other two genotypes in both cases ( $p<0.05$, see Figure 5). However, no significant differences in $G$ were found between the genotypes in Breiðafjörður $(F(2,146), p=0.9)$. When accounting for cohort as well as location, no consistent differences could be identified in fish growth rate between the genotypes in any of the three locations (see Figure 7 for example). 


\section{Discussion}

There were clear cohort-related variations in ecotype proportions in all three locations, with inversions in genotype dominance occurring between cohorts. The cod ecotypes have been shown to use similar spawning grounds (Jónsdóttir et al., 2008), with the separation in depth they inhabit during spawning season being no more than 50 meters (Bardarson et al., 2016), so it was to be expected that random sampling of these spawning grounds would yield proportions similar to those in the spawning population. No significant variation in proportions were detected between locations, despite the sampling in Breiðafjörður taking place at greater depth (Table 1) and the frequency of the B allele being positively correlated with depth (Pampoulie et al., 2006; Árnason et al., 2009). Overall, the intermediate ecotype (represented by the Pan $\mathrm{I}^{\mathrm{AB}}$ genotype) was most frequent in all three locations, as has been pointed out in other studies (Jónsdóttir et al., 2006), but there were also strong changes in genotype proportions among cohorts, both at shorter and longer time scales. As no such marked changes in proportions were found in genotype proportions for each sampling year, regardless of the cohort (Table 1), we conclude that the cohort-related variations were not due to biased sampling of the genotypes. If the changes in genotype proportions between cohorts were not the product of random variation, then the year-class strength of each ecotype would seem to vary. Similar temporal and spatial variations in ecotype proportions have also been noted along the Norwegian Skagerrak coast for the Fjord and North Sea ecotypes present there (Knutsen et al., 2018).

Discriminating ecotype identity using otolith shape yielded lower success than expected, both when using the Fourier and Wavelet coefficients. The low classification success of $68 \%$ contrasted with the higher overall classification success of $77 \%$ presented by Bardarson et al. (2016). They had most success classifying the frontal (90\%) and coastal (91\%) ecotypes, while the classification success in the present study was highest for the intermediate ecotype; the coastal and frontal ecotypes were usually misclassified as the intermediate ecotype in our study. It is therefore apparent that the otolith shape differences between the ecotypes were not strong enough to allow for successful discrimination. The distorting effect of the intermediate ecotype in the DFAs was evidenced by excluding this ecotype from the analyses, which increased the classification success for the Pan $\mathrm{I}^{\mathrm{AA}}$ and $\operatorname{Pan} \mathrm{I}^{\mathrm{BB}}$ genotypes to levels close to those reported by Bardarson et al. (2016) (Table 3). This is further supported by the distribution of the discriminant scores from the two-group DFA, along which the Pan $\mathrm{I}^{\mathrm{AA}}$ and $\operatorname{Pan} \mathrm{I}^{\mathrm{BB}}$ genotypes clearly separated. In contrast, the Pan $\mathrm{I}^{\mathrm{AB}}$ genotype discriminant scores from this analysis were distributed along the entire gradient between the Pan $\mathrm{I}^{\mathrm{AA}}$ and Pan $\mathrm{I}^{\mathrm{BB}}$ endpoints, indicating that the otolith shape of Pan $\mathrm{I}^{\mathrm{AB}}$ can range from a "Pan $\mathrm{I}^{\mathrm{AA}}$ shape" to a "Pan $\mathrm{I}^{\mathrm{BB}}$ shape" (Figure 4). This is consistent with DST data showing the $\mathrm{AB}$ genotype to present behaviour evenly distributed across the behaviour patterns

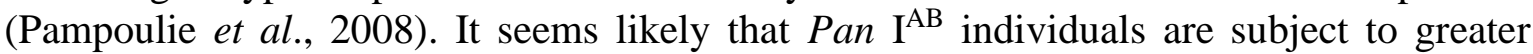
variation in environmental parameters such as temperature and food availability, which in turn affect otolith shape through fish growth (Hüssy, 2008; Irgens et al., 2017; Denechaud et al., 2020). Furthermore, the large temporal and spatial scale of our study almost certainly includes shape variation independent of the genotype which can affect the classification success for all genotypes. 
Both the Fourier and Wavelet descriptions of otolith shape were affected by fish growth. Calculating the growth rate index $(G)$ allows relative growth rate to be compared across different ages. Evaluating $G$ s effect on otolith shape indicated that growth rate, as well as cohort, had a significant effect on the otolith shape. While otolith shape is determined both by environmental and genetic influences (Vignon and Morat, 2010), a link between individual growth rate and otolith shape has repeatedly been found (Campana and Casselman, 1993; Oozeki and Watanabe, 2000; Simoneau et al., 2000; Strelcheck et al., 2003) and environmental variables have indeed been suggested to influence otolith shape through growth rate (Cardinale et al., 2004; Denechaud et al., 2020). The relationship between growth and shape presented here is concordant with other studies which have found that fish growth is an important factor to consider in stock discrimination based on otolith shape, as stocks with similar growth rates tend to have similar otolith shapes (Campana and Casselman, 1993; Begg and Brown, 2000). Thus, it is reasonable to extend that logic to the cod ecotypes - that their otolith shapes become more distinguishable with increasing differences in growth rate.

Variation in $G$ was greater between locations and among cohorts than between the ecotypes, which did not consistently present the growth rate differences previously suggested by literature (Jónsdóttir et al., 2002; Pálsson and Thorsteinsson, 2003; Jakobsdóttir et al., 2011). Spatial and temporal separation has not been considered in previous studies on the growth rate of the ecotypes, except in one case (Jónsdóttir et al., 2008), where the finding interestingly suggested that the relationship between growth rate and the Pan I genotypes was more complicated than previously thought and that growth rate varied more among spawning areas than among the Pan I genotypes within each area. Indeed, when comparing the variance in $G$ among locations, cohorts and Pan I identity, the identity did not have a significant effect on $G$, while both location and cohort were significant factors (Table 4). Although the spawning grounds sampled are only inhabited by these cod during a small part of the year, the fish still retain some spatial separation during the foraging season (Sólmundsson et al., 2015), and are thus exposed to different environments. A recent study on Northeast Arctic cod found environmental factors to exert a joint, indirect influence on otolith shape through changes in fish growth rate (Denechaud et al., 2020). Growth rate variations among locations and cohorts are common in fish and are strongly driven by temperature and food supply (Brandt et al., 1992; De Angelis et al., 1993), as is most likely the case here.

Growth rate's effect on discrimination analyses based on otolith shape has also been noted in other species, such as haddock (Melanogrammus aeglefinus) spawning components on Georges Bank (Begg and Brown, 2011), blue whiting (Micromesistius poutassou) morphotypes in the Northeast Atlantic (Keating et al., 2014) and herring (Clupea harengus) stock components in the Celtic and Irish seas (Burke et al., 2008). Otolith shape varied more with growth rate and cohort than with ecotype identity in the present study. This, and the greater variation in $G$ between locations and among cohorts than between ecotypes, suggests that ecotype-related variation in shape was masked by growth-driven variations in shape. As cod spawn in a number of areas around Iceland and each ecotype can be found in widely separate spawning grounds, individuals of the same ecotype are likely exposed to different environments, which can then influence the fish growth (Jónsdóttir et al., 2008). We conclude that any discrimination of ecotypes based on shape will have to take account of the spatial scale it encompasses, as the discrimination of individuals inhabiting different environments will be confounded by the variation in growth rate. 
Cod ecotypes have been reported elsewhere, with the Norwegian coastal and Northeast Arctic cod ecotypes being the most extensively studied. These are genetically distinct (Knutsen et al., 2018) and the ecotypes are readily distinguished using either internal or external otolith morphology (Stransky et al., 2008). Although such discrimination based on otoliths has not been successfully carried out on residential and migratory cod ecotypes in the Northwest Atlantic, cod ecotypes differing in body shape and coloration are readily distinguished in the Gulf of Maine (Sherwood and Grabowski, 2010) and genetic differentiation between spawning groups has been detected in the area (Clucas et al., 2019). Although not yet described as ecotypes, genetic differences indicating strong ecological adaptation have also been found between the western and eastern Baltic cod stocks (Weist et al., 2019).

The European anchovy (Engraulis encrasicolus) is another widely distributed marine fish that presents ecotypes, with genetic differentiation between coastal and offshore population pairs of the species consistently being found through its range, rendering genetic support to the previously identified phenotypic divergence between coastal and marine anchovies (Le Moan, 2016 and references therein). The most striking ecotype examples in fish are evidently found in freshwater, where impressive phenotypic and genetic divergence have taken place since the end of the last glacial period. Phenotypically and genetically divergent benthic and limnetic ecotypes have repeatedly been found for the threespine stickleback (Gasterosteus aculeatus) within the water systems they inhabit (Cresko and Baker, 1996; Smith et al., 2015). Such intra-lake divergence has also been noted in lake trout (Salvelinus namaychus), where ecotypes have developed independently in separate lake populations (Harris et al., 2015). Perhaps the clearest example of ecotype development is found in Arctic char (Salvelinus alpinus) in Pingvallavatn (Iceland), where significantly divergent ecotypes have developed rapidly in the last 10,000 years, offering an opportunity to study speciation (Skúlason et al., 1989; Kapralova et al., 2011, 2013; Guðbrandsson et al., 2019)). While the clear morphological differences between the Arctic char ecotypes make them readily distinguishable, the identification of ecotypes in other species can be more complicated, as is the case for cod in the present study.

Although discrimination of the Icelandic cod ecotypes by their otolith shape has been shown to yield some success here and in Bardarson et al. (2016), the method seems to be sensitive to both the broad distribution of the intermediate Pan $\mathrm{I}^{\mathrm{AB}}$ genotype as well as the effect of growth rate on shape, and therefore to temporal and spatial variations in growth. Combining this with the finding that the relationship between growth rate and ecotype is not as straightforward as previously suggested indicates that care must be taken to consider fish growth rate variations when otolith shape is studied. Otolith shape analysis is a promising morphological identification method for the Icelandic frontal and coastal cod ecotypes, but any such discrimination should be adjusted to account for temporal or spatial changes in growth rate, as these affect otolith shape. 


\section{Tables and Figures}

Table 1. Overview of the Pan I genetically identified samples originally presented in Jakobsdottir et al. (2011). Depth distributions (10-90\% quantiles) within location are presented where the exact depth of catch was unavailable (entries with asterisks). These samples were analyzed for their otolith shape and their growth rate index $(G)$ calculated.

\begin{tabular}{|c|c|c|c|c|c|c|c|c|}
\hline $\begin{array}{c}\text { Sampling } \\
\text { year }\end{array}$ & $\mathbf{n}$ & Location & $\begin{array}{l}\text { Depth } \\
\text { (m) }\end{array}$ & $\begin{array}{l}\text { Gear } \\
\text { type }\end{array}$ & AA & $A B$ & BB & $\begin{array}{l}\text { Nr. of } \\
\text { cohorts }\end{array}$ \\
\hline 1948 & 68 & BRE & 100 & Longline & $16 \%$ & $61 \%$ & $26 \%$ & 9 \\
\hline 1957 & 84 & SW & 37 & Gill net & $15 \%$ & $70 \%$ & $15 \%$ & 8 \\
\hline 1959 & 61 & SW & $\begin{array}{l}37- \\
74^{*}\end{array}$ & Gill net & $11 \%$ & $47 \%$ & $45 \%$ & 7 \\
\hline 1966 & 67 & SW & $\begin{array}{l}37- \\
74 *\end{array}$ & $\begin{array}{l}\text { Bottom } \\
\text { trawl }\end{array}$ & $4 \%$ & $87 \%$ & $9 \%$ & 7 \\
\hline 1972 & 69 & FAX & $\begin{array}{l}38- \\
83^{*}\end{array}$ & Gill net & $4 \%$ & $70 \%$ & $26 \%$ & 6 \\
\hline 1973 & 73 & SW & 70 & Gill net & $3 \%$ & $81 \%$ & $16 \%$ & 6 \\
\hline 1976 & 52 & FAX & 55 & Gill net & $35 \%$ & $65 \%$ & $0 \%$ & 6 \\
\hline 1976 & 47 & SW & 45 & $\begin{array}{l}\text { Bottom } \\
\text { trawl }\end{array}$ & $70 \%$ & $28 \%$ & $2 \%$ & 6 \\
\hline 1979 & 61 & FAX & 50 & Gill net & $0 \%$ & $98 \%$ & $2 \%$ & 5 \\
\hline 1985 & 73 & SW & $\begin{array}{l}37- \\
74^{*}\end{array}$ & Gill net & $19 \%$ & $55 \%$ & $26 \%$ & 8 \\
\hline 1996 & 40 & BRE & 63 & Gill net & $28 \%$ & $72 \%$ & $0 \%$ & 5 \\
\hline 1996 & 25 & FAX & 55 & Gill net & $92 \%$ & $8 \%$ & $0 \%$ & 5 \\
\hline 1996 & 68 & SW & 56 & Gill net & $57 \%$ & $43 \%$ & $0 \%$ & 8 \\
\hline 2000 & 38 & BRE & 150 & Gill net & $21 \%$ & $66 \%$ & $13 \%$ & 5 \\
\hline
\end{tabular}


Table 2. Classification success (\%) of the Pan I genotypes by Discriminant function analyses of otolith shape. Overall classification success was between 64 and $68 \%$ for all analyses. $N=826$ for each analysis.

\begin{tabular}{|c|c|c|c|}
\hline Model & Pan IA & Pan $\mathrm{I}^{\mathrm{AB}}$ & Pan $\mathrm{I}^{\mathrm{BB}}$ \\
\hline Pan I Wavelet & 17.0 & 94.5 & 5.0 \\
\hline Pan I Fourier & 29.1 & 92.6 & 5.0 \\
\hline Pan I Wavelet + cohort + G & 34.1 & 93.1 & 2.5 \\
\hline Pan I Fourier + cohort + G & 39.0 & 91.8 & 1.7 \\
\hline
\end{tabular}

Table 3. Classification success (\%) of the Pan $I^{A A}$ and Pan $I^{B B}$ genotypes by Discriminant function analyses of otolith shape. $N=826$ for each analysis.

\begin{tabular}{lcc} 
& $\operatorname{Pan} \mathrm{I}^{\mathrm{AA}}$ & $\operatorname{Pan~}^{\mathrm{BB}}$ \\
\hline Man I Wavelet + cohort + G & 87.9 & 72.3 \\
\hline Pan I Fourier + cohort + G & 85.2 & 74.8
\end{tabular}


Table 4. Results of a three-way ANOVA evaluating the relative effect of location, cohort and Pan I identity on the growth rate index $(G)$, as well as their two-way interactions.

\begin{tabular}{lccccc} 
& $\begin{array}{c}\text { Type III } \\
\text { Sum of } \\
\text { Squares }\end{array}$ & df & $\begin{array}{c}\text { Mean } \\
\text { Square }\end{array}$ & F & $\boldsymbol{p}$ \\
\hline Corrected Model & 37523 & 146 & 257 & 5.3 & $<0.000$ \\
\hline Intercept & 3 & 1 & 3.0 & 0.062 & $<0.804$ \\
\hline Pan I & 43 & 2 & 21.9 & 0.45 & $<0.638$ \\
\hline Location & 1965 & 2 & 982.7 & 20.2 & $<0.000$ \\
\hline Cohort & 11728 & 55 & 213.3 & 4.4 & $<0.000$ \\
\hline Location * Cohort & 2195 & 19 & 115.6 & 2.4 & $<0.001$ \\
\hline Pan I Cohort & 3945 & 64 & 61.6 & 1.3 & $<0.085$ \\
\hline Pan I ${ }^{*}$ Location & 28 & 3 & 9.5 & 0.19 & $<0.900$ \\
\hline Error & 33037 & 679 & 48.7 & & \\
\hline Total & 70561 & 826 & & & \\
\hline Corrected Total & 70561 & 825 & & & \\
\hline
\end{tabular}




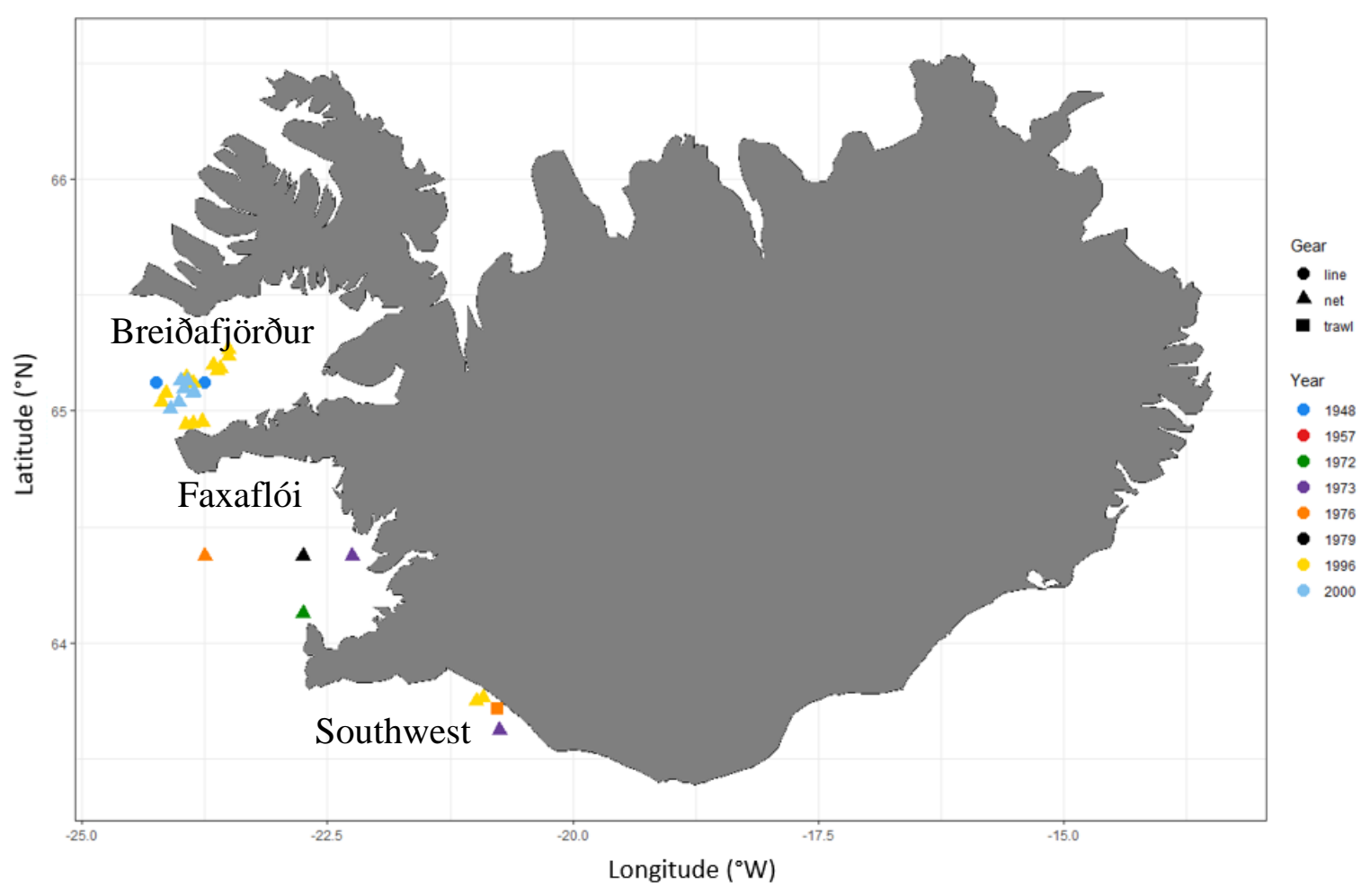

Figure 1. Map of the sampling locations. Colour indicates sampling year and shape indicates gear type. 


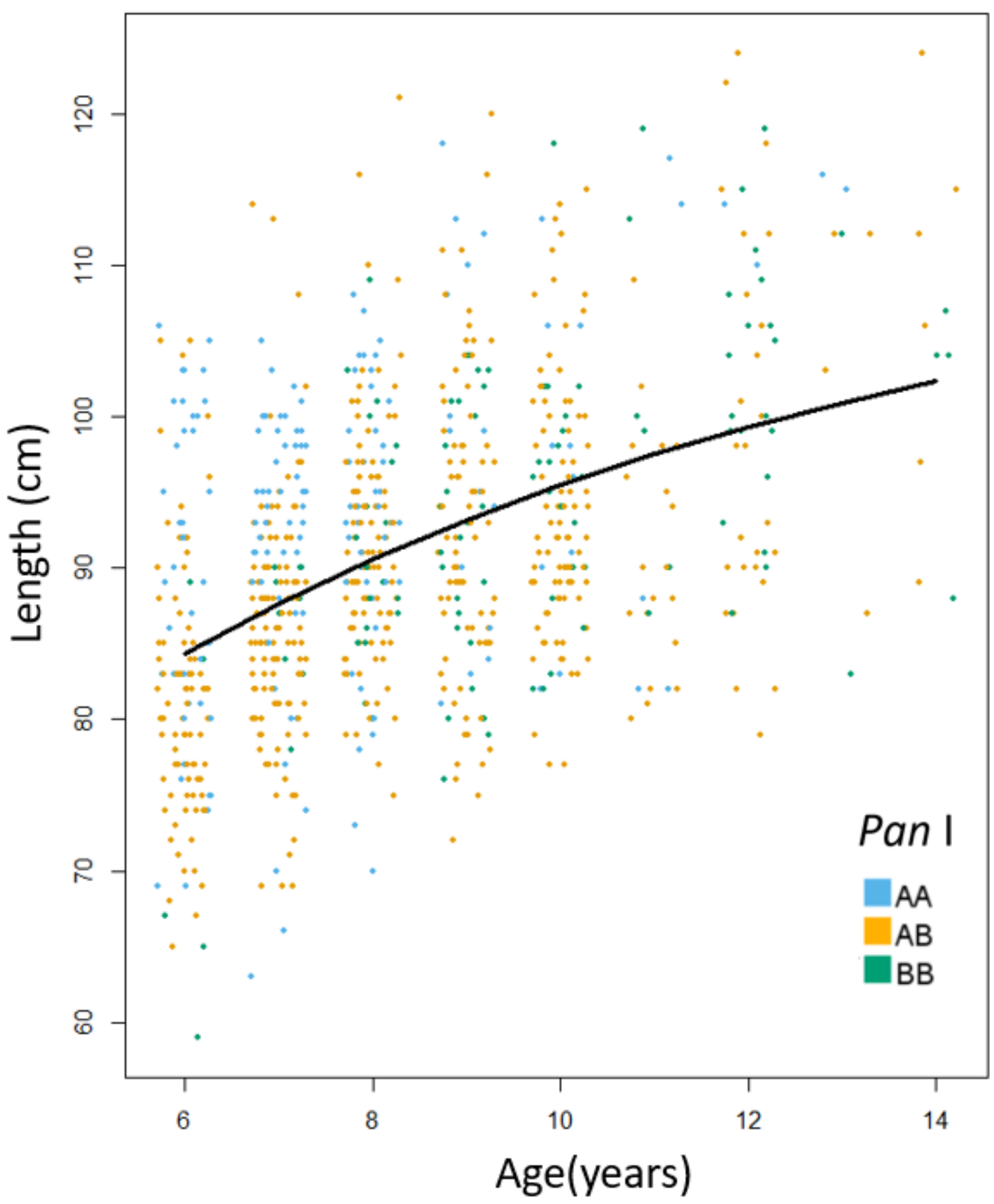

Figure 2. A von Bertalanffy growth curve fitted to the length-at-age data. Each dot represents an individual and its residual from the curve is the individual's relative growth rate $(G) . N=826$. Data are jittered within age-groups. 

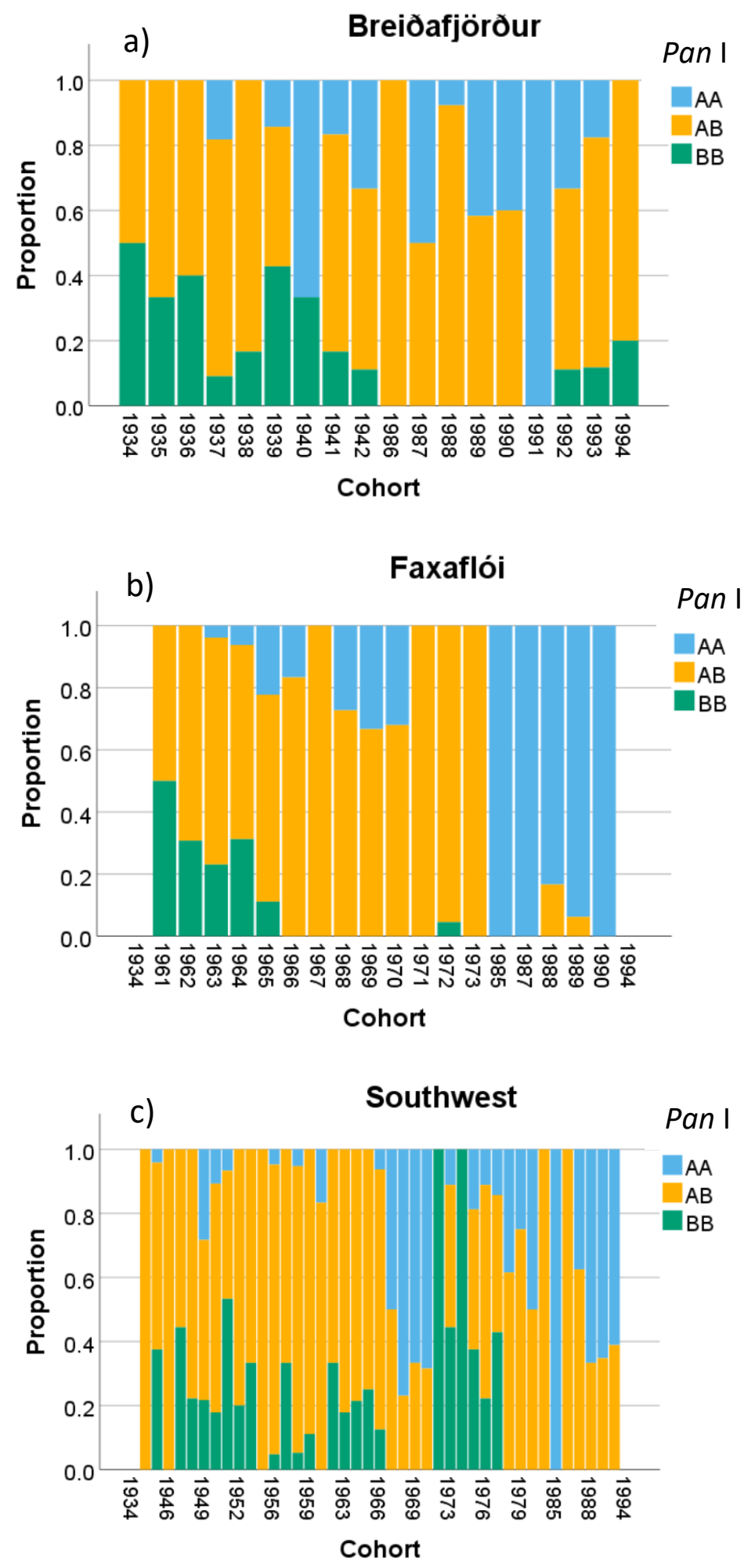

Figure 3. Relative proportions of the three Pan I genotypes across cohorts in the three sampling locations: a) Breiðafjörður $(n=146)$, b) Faxafloi $(n=207)$ and c) Southwest $(n=473)$. Note different scales on the $x$-axes. 

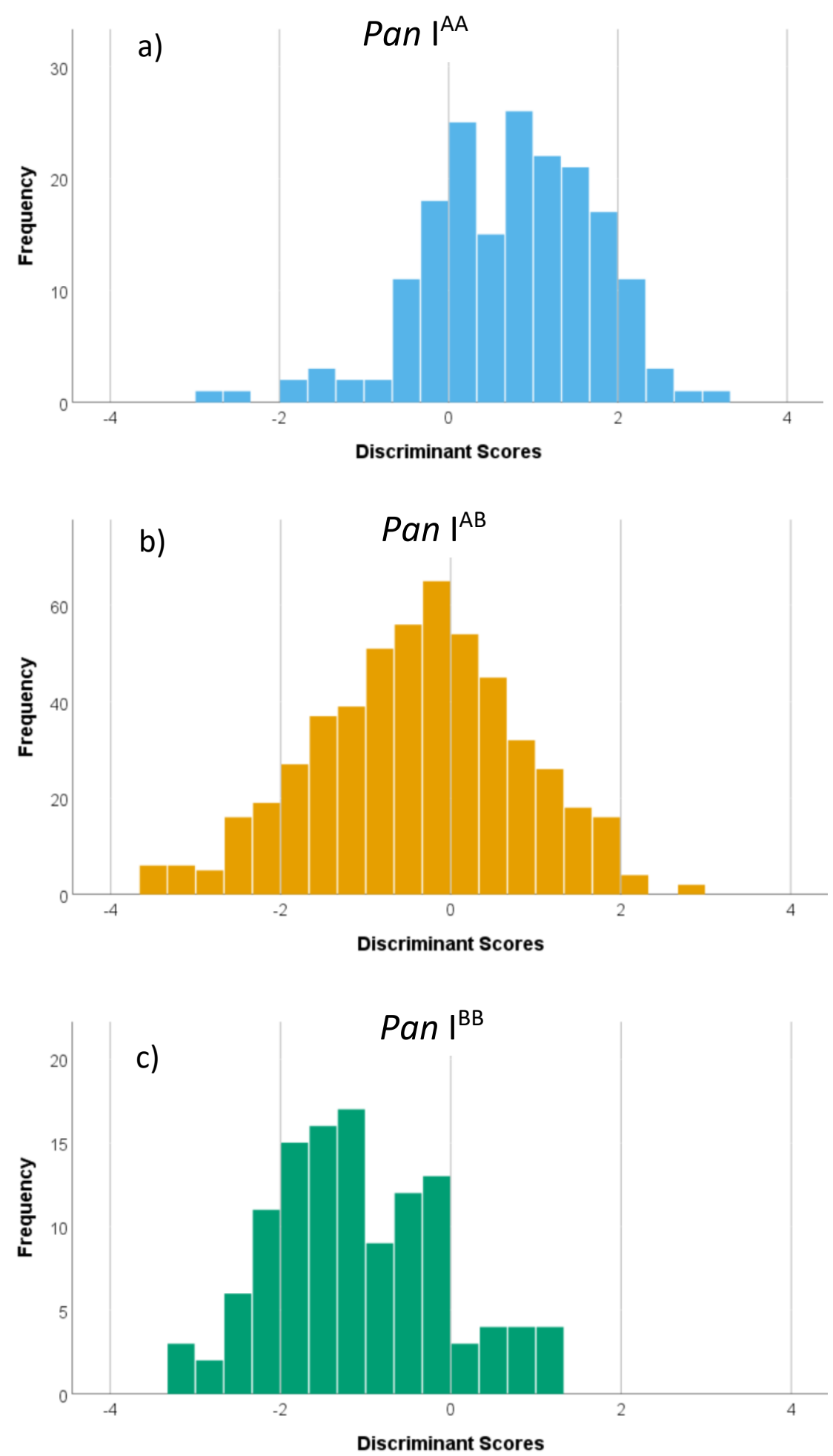

Figures 4a-c. Distributions of the three Pan I genotypes along the discriminant scores from a Discriminant function analysis of the Pan $I^{A A}$ and $\operatorname{Pan} I^{B B}$ genotypes using Wavelet coefficients, cohort and the growth rate index $(G)$. 


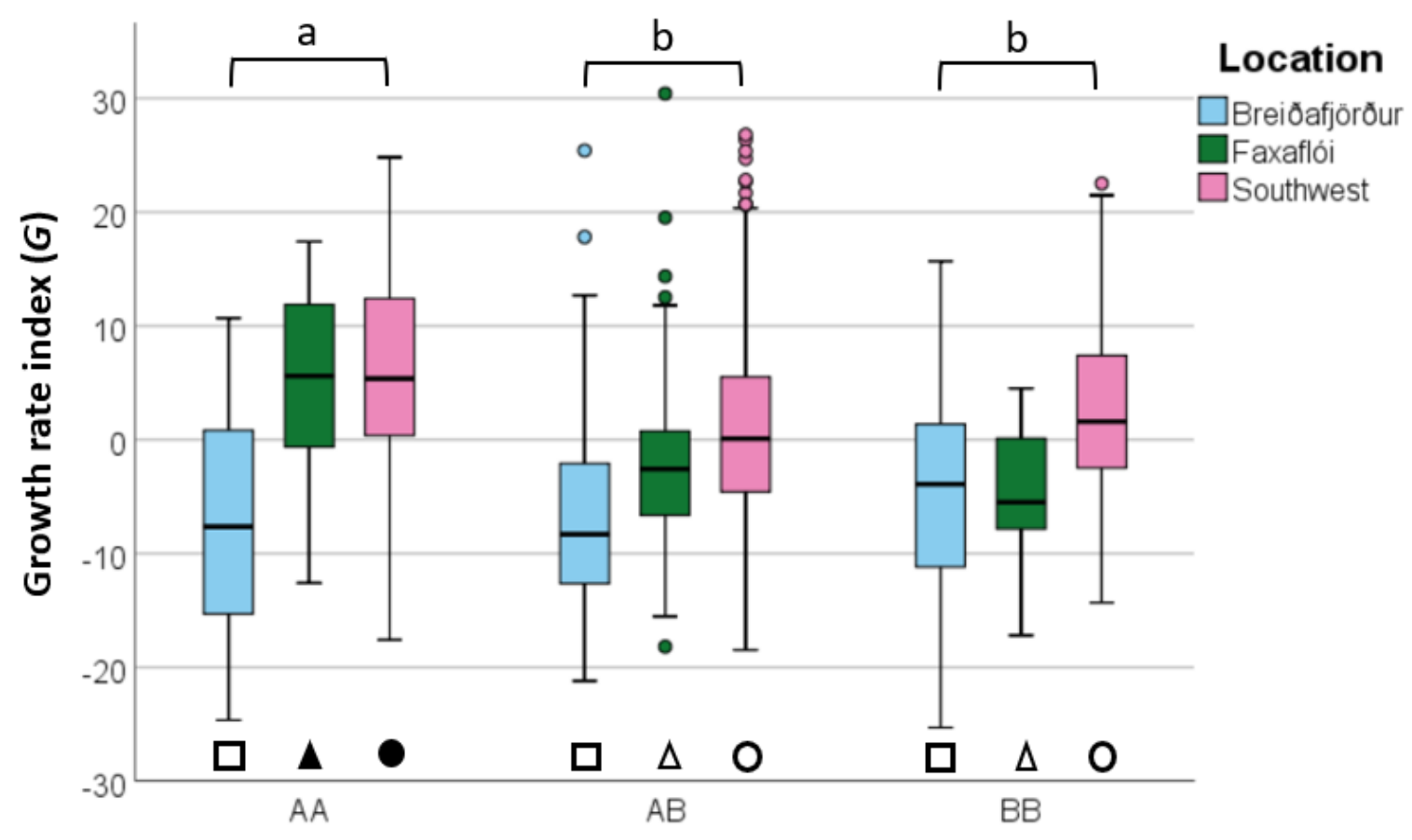

Pan I identity

Figure 5. Growth rate index $(G)$ for the ecotypes represented by the Pan I genotypes. Letters indicate significant differences among Pan I genotypes pooled across locations while shape and fill indicate significant differences among Pan I genotypes within each location. Error bars represent $95 \%$ confidence interval.

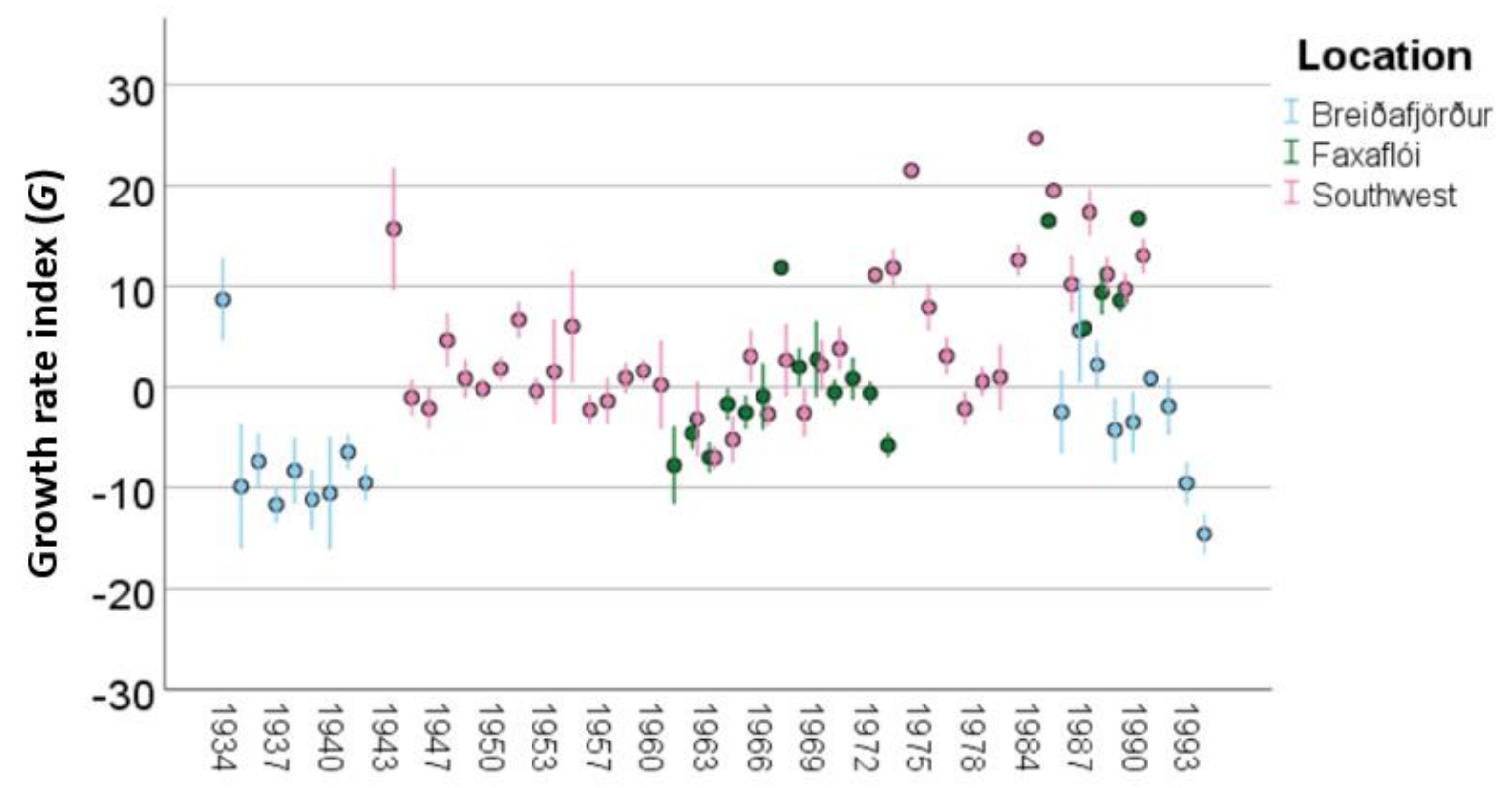

Cohort

Figure 6. Variation in the growth rate index $(G)$ across cohorts and among locations. Error bars indicate one standard error. 


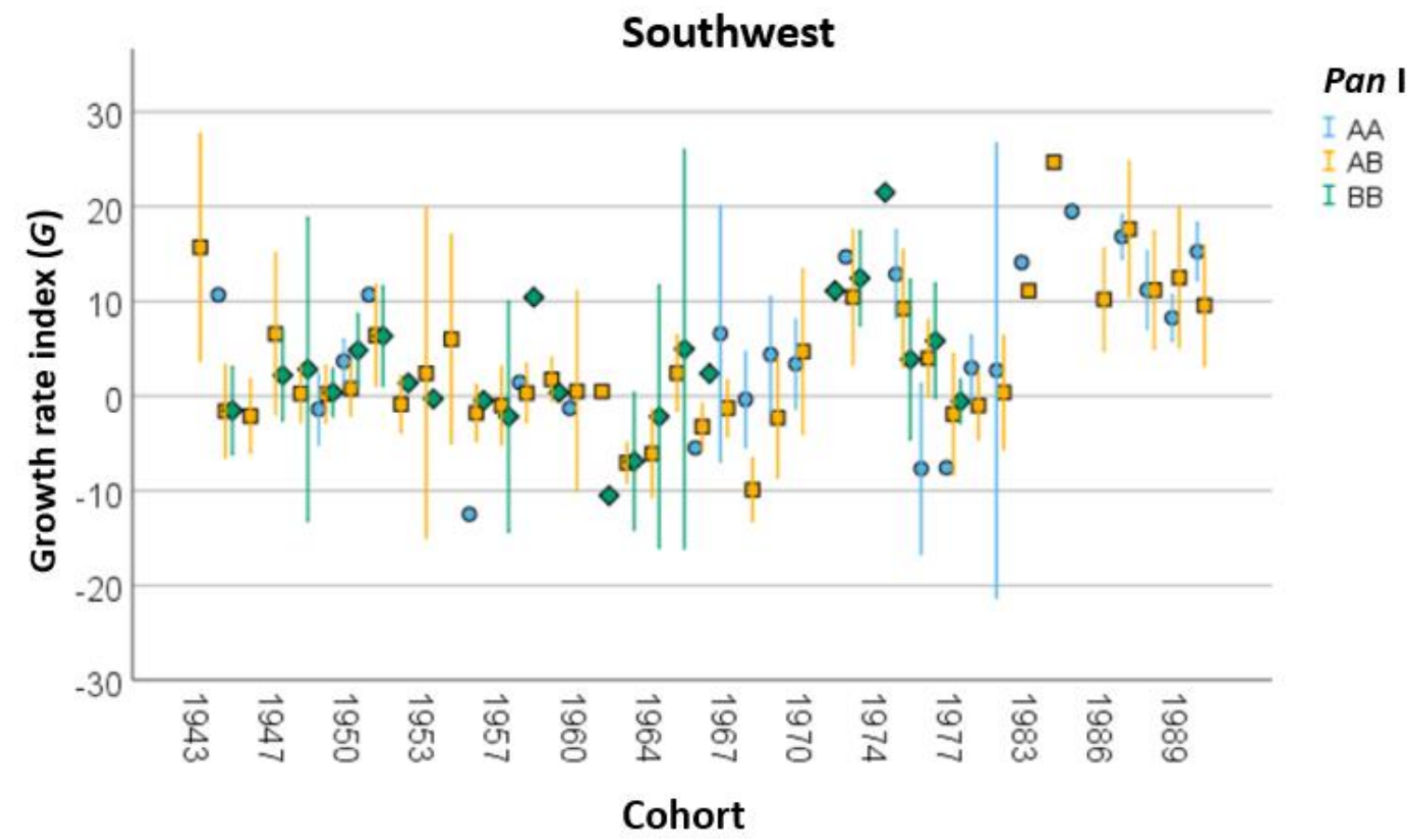

Figure 7. Growth rate $(G)$ of the Pan I genotypes across cohorts in the Southwest location. Error bars indicate one standard error. 


\section{References}

Árnason, E., Hernandez, U. B., and Kristinsson, K. 2009. Intense habitat-specific fisheriesinduced selection at the molecular Pan I locus predicts imminent collapse of a major cod fishery. PLoS ONE, 4. https://doi.org/10.1371/journal.pone.0005529

Bardarson, H., Mcadam, B. J., Petursdottir, G., and Marteinsdottir, G. 2014. To glue or not to glue? Reassembling broken otoliths for population discrimination. Journal of Fish Biology, 84: 1626-1633. https://doi.org/10.1111/jfb.12390

Bardarson, H., McAdam, B. J., Thorsteinsson, V., Hjorleifsson, E., and Marteinsdottir, G. 2016. Otolith shape differences between ecotypes of Icelandic cod (Gadus morhua) with known migratory behaviour inferred from Data Storage Tags. Canadian Journal of Fisheries and Aquatic Sciences, 9: 1-46. https://doi.org/10.1139/cjfas-2016-0307

Begg, G. A., and Brown, R. W. 2000. Stock Identification of Haddock Melanogrammus aeglefinus on Georges Bank Based on Otolith Shape Analysis. Transactions of the American Fisheries Society, 129: 935-945.

Brandt, S. B., Mason, D. M., and Patrick, E. V. 1992. Spatially-explicit Models of Fish Growth Rate. Fisheries, 17: 23-35.

Burke, N., Brophy, D., and King, P. A. 2008. Shape analysis of otolith annuli in Atlantic herring (Clupea harengus); a new method for tracking fish populations. Fisheries Research, 91: 133-143.

Campana, S. E., and Casselman, J. M. 1993. Stock discrimination using otolith shape analysis. Canadian Journal of Fisheries and Aquatic Sciences, 50: 1062-1083. https://doi.org/10.1139/f93-123

Campana, S. E. 2005. Otolith science entering the 21st century. In Marine and Freshwater Research, pp. 485-495. https://doi.org/10.1071/MF04147

Cardinale, M., Doering-Arjes, P., Kastowsky, M., and Mosegaard, H. 2004. Effects of sex, stock, and environment on the shape of known-age Atlantic cod (Gadus morhua) otoliths. Canadian Journal of Fisheries and Aquatic Sciences, 61: 158-167. https://doi.org/10.1139/f03-151

Clucas, G. V., Kerr, L. A., Cadrin, S. X., Zemeckis, D. R., Sherwood, G. D., Goethel, D., Whitener, Z., et al. 2019. Adaptive genetic variation underlies biocomplexity of Atlantic Cod in the Gulf of Maine and on Georges Bank. PLoS ONE, 14: 1-24. https://doi.org/10.1371/journal.pone.0216992

Cresko, W. A., and Baker, J. A. 1996. Two morphotypes of lacustrine threespine stickleback, Gasterosteus aculeatus, in Benka Lake, Alaska. Environmental Biology of Fishes, 45: 343-350. 
De Angelis, D. L., Rose, K. A., Crowder, L. B., Marschall, E. A., and Lika, D. 1993. Fish cohort dynamics: Application of complementary modeling approaches. American Naturalist, 142: 604-622.

Denechaud, C., Smoliński, S., Geffen, A. J., and Godiksen, J. A. 2020. Long-term temporal stability of Northeast Arctic cod (Gadus morhua) otolith morphology. ICES Journal of Marine Science. https://doi.org/10.1093/icesjms/fsz259

Francis, R. I. C. C. 1988. Are growth parameters estimated from tagging and age-length data comparable? Canadian Journal of Fisheries and Aquatic Sciences, 45: 936-942. https://doi.org/10.1139/f88-115

Guðbrandsson, J., Kapralova, K. H., Franzdóttir, S. R., Bergsveinsdóttir, P. M., Hafstað, V., Jónsson, Z. O., Snorrason, S. S., et al. 2019. Extensive genetic differentiation between recently evolved sympatric Arctic charr morphs. Ecology and Evolution, 9:1096410983. https://doi.org/10.1002/ece3.5516

Grabowski, T. B., Thorsteinsson, V., McAdam, B. J., and Marteinsdóttir, G. 2011.

Evidence of segregated spawning in a single marine fish stock: Sympatric divergence of ecotypes in Icelandic cod? PLoS ONE, 6(3), e17528.

https://doi.org/10.1371/journal.pone.0017528

Graps, A. 1995. An Introduction to Wavelets. IEEE Computational Science and Engineering.

Harris, L. N., Chavarie, L., Bajno, R., Howland, K. L., Wiley, S. H., Tonn, W. M., and Taylor, E. B. 2015. Evolution and origin of sympatric shallow-water morphotypes of Lake Trout, Salvelinus namaycush, in Canada's Great Bear Lake. Heredity, 114: 94106. Nature Publishing Group.

Hüssy, K. 2008. Otolith shape in juvenile cod (Gadus morhua): Ontogenetic and environmental effects. Journal of Experimental Marine Biology and Ecology, 364: 3541. https://doi.org/10.1016/j.jembe.2008.06.026

IBM Corp. Released 2019. IBM SPSS Statistics for Windows, Version 26.0. Armonk, NY: IBM Corp.

Irgens, C., Kjesbu, O. S., and Folkvord, A. 2017. Ontogenetic development of otolith shape during settlement of juvenile Barents Sea cod (Gadus morhua). ICES Journal of Marine Science, 74: 2389-2397. https://doi.org/10.1093/icesjms/fsx088

Jakobsdóttir, K. B., Pardoe, H., Magnússon, Á., Björnsson, H., Pampoulie, C., Ruzzante, D. E., Marteinsdóttir, G., et al. 2011. Historical changes in genotypic frequencies at the Pantophysin locus in Atlantic cod (Gadus morhua) in Icelandic waters: Evidence of fisheries-induced selection? Evolutionary Applications, 4: 562-573. https://doi.org/10.1111/j.1752-4571.2010.00176.x

Johnson, Z. I., Zinser, E. R., Coe, A., McNulty, N. P., Woodward, E. M. S., and Chisholm, S. W. 2006. Niche partitioning among Prochlorococcus ecotypes along ocean-scale environmental gradients. Science, 311: 1737-1740. doi: 10.1126/science.1118052 
Jónsdóttir, I. G., Campana, S. E., and Marteinsdottir, G. 2006. Otolith shape and temporal stability of spawning groups of Icelandic cod (Gadus morhua L.). ICES Journal of Marine Science, 63: 1501-1512. https://doi.org/10.1016/j.icesjms.2006.05.006

Jónsdóttir, I. G., Marteinsdóttir, G., and Pampoulie, C. 2008. Relation of growth and condition with the Pan I locus in Atlantic cod (Gadus morhua L.) around Iceland. Marine Biology, 154: 867-874.

Jónsdóttir, Ó. D. B., Imsland, A. K., Daníelsdóttir, A. K., and Marteinsdóttir, G. 2002. Genetic heterogeneity and growth properties of different genotypes of Atlantic cod (Gadus morhua L.) at two spawning sites off south Iceland. Fisheries Research, 55: 3747. https://doi.org/10.1016/S0165-7836(01)00296-X

Kapralova, K. H., Morrissey, M. B., Kristjánsson, B. K., Lafsdóttir, G. Á., Snorrason, S. S., and Ferguson, M. M. 2011. Evolution of adaptive diversity and genetic connectivity in Arctic charr (Salvelinus alpinus) in Iceland. Heredity, 106: 472-487.

Kapralova, K. H., Gudbrandsson, J., Reynisdottir, S., Santos, C. B., Baltanás, V. C., Maier, V. H., Snorrason, S. S., et al. 2013. Differentiation at the MHCII $\alpha$ and Cath2 Loci in Sympatric Salvelinus alpinus Resource Morphs in Lake Thingvallavatn. PLoS ONE, 8. https://doi.org/10.1371/journal.pone.0069402

Keating, J. P., Brophy, D., Officer, R. A., and Mullins, E. 2014. Otolith shape analysis of blue whiting suggests a complex stock structure at their spawning grounds in the Northeast Atlantic. Fisheries Research, 157: 1-6. Elsevier B.V. https://doi.org/10.1016/j.fishres.2014.03.009

Knutsen, H., Jorde, P. E., Hutchings, J. A., Hemmer-Hansen, J., Grønkjaer, P., Jørgensen, K.-E. M., André, C., et al. 2018. Stable coexistence of genetically divergent Atlantic cod ecotypes at multiple spatial scales. Evolutionary Applications: 1-13. http://doi.wiley.com/10.1111/eva.12640.

Le Moan, A., Gagnaire, P. A., and Bonhomme, F. 2016. Parallel genetic divergence among coastal-marine ecotype pairs of European anchovy explained by differential introgression after secondary contact. Molecular Ecology, 25: 3187-3202. https://doi.org/10.1111/mec.13627

Libungan, L. A., and Pálsson, S. 2015. ShapeR: An R package to study otolith shape variation among fish populations. PLoS ONE, 10: 1-12. https://doi.org/10.1371/journal.pone.0121102

Lombarte, A., and Lleonart, J. 1993. Otolith size changes related with body growth, habitat depth and temperature. Environmental Biology of Fishes, 37: 297-306.

Lowry, D. B. 2012. Ecotypes and the controversy over stages in the formation of new species. Biological Journal of the Linnean Society, 106: 241-257. https://doi.org/10.1111/j.1095-8312.2012.01867.x

Marteinsdottir, G., Gunnarsson, B., and Suthers, I. M. 2000. Spatial variation in hatch date distributions and origin of pelagic juvenile cod in Icelandic waters. ICES Journal of Marine Science, 57: 1182-1195. https://doi.org/10.1006/jmsc.2000.0880 
Nelson, G.A. (2018). fishmethods: Fishery Science Methods and Models. R package version 1.11-0. https://CRAN.R-project.org/package=fishmethods

Oozeki, Y., and Watanabe, Y. 2000. Comparison of somatic growth and otolith increment growth in laboratory-reared larvae of Pacific saury, Cololabis saira, under different temperature conditions. Marine Biology, 136: 349-359.

Pálsson, Ó. K., and Thorsteinsson, V. 2003. Migration patterns, ambient temperature, and growth of Icelandic cod (Gadus morhua): evidence from storage tag data. Canadian Journal of Fisheries and Aquatic Sciences, 60: 1409-1423. http://www.nrcresearchpress.com/doi/10.1139/f03-117.

Pampoulie, C., Ruzzante, D. E., Chosson, V., Jörundsdóttir, T. D., Taylor, L., Thorsteinsson, V., Daníelsdóttir, A. K., et al. 2006. The genetic structure of Atlantic cod (Gadus morhua) around Iceland: insight from microsatellites, the Pan I locus, and tagging experiments. Canadian Journal of Fisheries and Aquatic Sciences, 63: 2660-2674. http://www.nrcresearchpress.com/doi/10.1139/f06-150.

Pampoulie, C., Jakobsdóttir, K. B., Marteinsdóttir, G., and Thorsteinsson, V. 2008. Are Vertical Behaviour Patterns Related to the Pantophysin Locus in the Atlantic cod (Gadus morhua L.)? Behavior Genetics, 38: 76-81. http://link.springer.com/10.1007/s10519-007-9175-y.

Pardoe, H., and Marteinsdóttir, G. 2009. Contrasting trends in two condition indices: Bathymetric and spatial variation in autumn condition of Icelandic cod Gadus morhua. Journal of Fish Biology, 75: 282-289. https://doi.org/10.1111/j.10958649.2009.02273.x

R Core Team. 2020. R: A language and environment for statistical computing. http://www.R-project.org/

Robichaud, D., and Rose, G. A. 2004. Migratory behaviour and range in Atlantic cod: Inference from a century of tagging. Fish and Fisheries, 5: 185-214. https://doi.org/10.1111/j.1467-2679.2004.00141.x

Rogers, S. M., Gagnon, V., and Bernatchez, L. 2002. Genetically based phenotypeenvironment association for swimming behavior in lake whitefish ecotypes (Coregonus clupeaformis Mitchill). $\quad$ Evolution. https://doi.org/10.1111/j.00143820.2002.tb00155.x

Schindelin, J., Arganda-Carreras, I., Frise, E., Kaynig, V., Longair, M., Pietzsch, T., Preibisch, S., et al. 2012. Fiji: An open-source platform for biological-image analysis.

Sherwood, G. D., and Grabowski, J. H. 2010. Exploring the life-history implications of colour variation in offshore Gulf of Maine cod (Gadus morhua). ICES Journal of Marine Science, 67: 1640-1649. https://doi.org/10.1093/icesjms/fsq094

Simoneau, M., Casselman, J. M., and Fortin, R. 2000. Determining the effect of negative allometry (length/height relationship) on variation in otolith shape in lake trout (Salvelinus namaycush), using Fourier-series analysis. Canadian Journal of Zoology, 78: 1597-1603. https://doi.org/10.1139/z00-093 
Skúlason, S., Noakes, D. L. G., and Snorrason, S. S. 1989. Ontogeny of trophic morphology in four sympatric morphs of arctic charr Salvelinus alpinus in Thingvallavatn, Iceland. Biological Journal of the Linnean Society, 38: 281-301.

Smith, G., Smith, C., Kenny, J. G., Chaudhuri, R. R., and Ritchie, M. G. 2015. Genomewide DNA methylation patterns in wild samples of two morphotypes of threespine stickleback (Gasterosteus aculeatus). Molecular Biology and Evolution, 32: 888-895.

Sólmundsson, J., Jónsdóttir, I. G., Björnsson, B., Ragnarsson, S. A., Tómasson, G. G., and Thorsteinsson, V. 2015. Home ranges and spatial segregation of cod Gadus morhua spawning components. Marine Ecology Progress Series, 520: 217-233. https://doi.org/10.3354/meps11106

Stransky, C., Baumann, H., Fevolden, S. E., Harbitz, A., Høie, H., Nedreaas, K. H., Salberg, A. B., et al. 2008. Separation of Norwegian coastal cod and Northeast Arctic cod by outer otolith shape analysis. Fisheries Research, 90: 26-35. https://doi.org/10.1016/j.fishres.2007.09.009

Strelcheck, A. J., Fitzhugh, G. R., Coleman, F. C., and Koenig, C. C. 2003. Otolith-fish size relationship in juvenile gag (Mycteroperca microlepis) of the eastern Gulf of Mexico: A comparison of growth rates between laboratory and field populations. Fisheries Research, 60: 255-265. https://doi.org/10.1016/S0165-7836(02)00171-6

Thorsteinsson, V., Pálsson, Ó. K., Tómasson, G. G., Jónsdóttir, I. G., and Pampoulie, C. 2012. Consistency in the behaviour types of the Atlantic cod: Repeatability, timing of migration and geo-location. Marine Ecology Progress Series, 462: 251-260. https://doi.org/10.3354/meps09852

Turesson, G. 1922. The Species and the variety as Ecological Units. Hereditas.

Vignon, M., and Morat, F. 2010. Environmental and genetic determinant of otolith shape revealed by a non-indigenous tropical fish. Marine Ecology Progress Series, 411: 231241. https://doi.org/10.3354/meps08651

Weist, P., Schade, F. M., Damerau, M., Barth, J. M. I., Dierking, J., André, C., Petereit, C., et al. 2019. Assessing SNP-markers to study population mixing and ecological adaptation in Baltic cod. PLoS ONE, 14: 1-16. https://doi.org/10.1371/journal.pone.0218127

Wood, C. C., Bickham, J. W., John Nelson, R., Foote, C. J., and Patton, J. C. 2008. Recurrent evolution of life history ecotypes in sockeye salmon: implications for conservation and future evolution. Evolutionary Applications, 1: 207-221. https://doi.org/10.1111/j.1752-4571.2008.00028.x 

